\title{
Effect of isolation on coat colour polymorphism of Polynesian rats in Island Southeast Asia and the Pacific
}

\author{
Alexandra AE van der Geer ${ }^{\text {Corresp. } 1}$ \\ ${ }^{1}$ Naturalis Biodiversity Center, Leiden, Netherlands \\ Corresponding Author: Alexandra AE van der Geer \\ Email address: alexandra.vandergeer@naturalis.nl
}

Populations of vertebrate species introduced onto islands regularly develop similar phenotypic changes, e.g. larger or smaller body size, shortened limbs, duller coats, as well as behavioural changes such as increased tameness and reduced flight-initiation distance. These changes overlap in part with those associated with the 'domestication syndrome', especially tameness and changes in coat patterns, and might indicate a similar neural crest involvement in the concurrent development of multiple phenotypic traits. Here I examine long-term data on free-living populations of wild Polynesian rats from seven mainland countries and 117 islands ( $n=3034)$, covering the species' native and introduced range. Mainland populations showed no aberrant coat patterns, with the exception of one albino, whereas aberrant coat patterns were found in 12 island populations. Observed coat colour polymorphisms consisted of leucistic (including singular white patches), melanistic (darkly pigmented) and piebald (mixed) coat patterns. After isolation for at least seven centuries, wild Polynesian rat populations on islands seem to exhibit a trend towards a higher incidence of aberrant coat patterns. These phenotypic changes are here explained as a neutral, non-adaptive process, likely part of the 'domestication syndrome' (via the commensal pathway of domestication), in combination with genetic drift, little or no gene flow between the islands and/or the mainland and a relaxed selection (as a result of the weakening or removal of competitor / predator pressure) under commensality. 


\section{Effect of isolation on coat colour patterns of \\ 2 Polynesian rats in Island Southeast Asia and the \\ 3 Pacific}

4 Alexandra A.E. van der Geer ${ }^{1}$

$5 \quad{ }^{1}$ Naturalis Biodiversity Center, Leiden, the Netherlands

6 Corresponding author

7 Alexandra van der Geer

8 Darwinweg 2, 2333 CR Leiden, the Netherlands

9 E-mail address: alexandra.vandergeer@naturalis.nl

\section{Abstract}

Populations of vertebrate species introduced onto islands regularly develop similar phenotypic changes, e.g. larger or smaller body size, shortened limbs, duller coats, as well as behavioural changes such as increased tameness and reduced flight-initiation distance. These changes overlap in part with those associated with the 'domestication syndrome', especially tameness and changes in coat patterns, and might indicate a similar neural crest involvement in the concurrent development of multiple phenotypic traits. Here I examine long-term data on free-living populations of wild Polynesian rats from seven mainland countries and 117 islands $(n=3034)$, covering the species' native and introduced range. Mainland populations showed no aberrant coat patterns, with the exception of one albino, whereas aberrant coat patterns were found in 12 island populations. Observed coat colour polymorphisms consisted of leucistic (including singular white patches), melanistic (darkly pigmented) and piebald (mixed) coat patterns. After isolation for at least seven centuries, wild Polynesian rat populations on islands seem to exhibit a trend towards a higher incidence of aberrant coat patterns. These phenotypic changes are here explained as a neutral, non-adaptive process, likely part of the 'domestication syndrome' (via the commensal pathway of domestication), in combination with genetic drift, little or no gene flow between the islands and/or the mainland and a relaxed selection (as a result of the weakening or removal of competitor / predator pressure) under commensality.

Evolution on islands has often led to increased phenotypic variation and phenotypic novelty not observed in closely related mainland forms, inspiring studies on evolution ever since Wallace wrote his influential book (1880). The perhaps most obvious phenotypic variation is observed in 
and pony-sized elephants and hippos were common elements of island faunas (van der Geer et al., 2010). Body mass evolution of island mammals typically follows a graded trend from gigantism in small-sized species to dwarfism in large-sized species (Foster, 1964; Van Valen, 1973; Lomolino, 1985, 2005), where the degree and direction of body size evolution vary in a predictable manner in accordance with characteristics of the ancestral taxon and the levels and nature of various factors like competition, predation, ecological complexity, climate, latitude, island area and isolation (Lomolino et al., 2012, 2013). Other morphological features regularly shared by phylogenetically distant fossil island mammals are proportionally shortened limbs (Sondaar, 1977), reduced brain size (Weston \& Lister, 2009; see, however, Lyras et al., 2006), increased convolution of the brain cortex (Desachaux, 1961; Falk et al., 2005), fusions of limb bones (Leinders \& Sondaar, 1974; Moyá-Solá, 1979; van den Bergh et al., 2008; van der Geer, 2014), high-crowned teeth (Bover, 2004; van den Bergh, 1999; van der Geer et al., 2006; van der Made, 1999), loss of dental elements (Leinders, 1984; Lyras et al., 2006; Boekschoten \& Sondaar, 1972), shortened muzzles (van der Geer, 2005; Quintana, Köhler \& Moyà-Solà, 2011; Kaifu et al., 2011; van der Geer et al., 2018), increased stereoscopy (van der Geer, 2005) and increased size variation (de Vos \& van der Geer, 2002; van der Geer, 2014). Isolated mammal populations may also show shared ecological differences such as increased tameness or ecological naiveté (see also below), higher and more stable population densities, reduced intraspecific aggression, reduced reproductive output (see, however, Raia, Barbera \& Conte, 2003, who suggested increased reproductive productivity in a dwarf elephant) and reduced dispersal abilities. The suite of ecological and morphological characters often associated with isolated mammal populations is referred to as the 'island syndrome' (Adler and Levins, 1994). Other groups, e.g. lizards, also show trait shifts that are consistent with the 'island syndrome', such as a higher degree of melanism (darkly pigmented skins) (Runemark et al., 2010), increased tameness (Cooper \& Pérez-Mellado, 2012), shorter flight initiation distance and reduced sprint speed (Vervust, Grab \& van Damme, 2007), smaller clutch sizes (Huang, 2007) and larger bodies (Vervust, Grab \& van Damme, 2007; Pafilis et al., 2009). In parallel, insular birds may have smaller clutch sizes (Cody, 1971), dull colours (Omland, 1997), increased tameness (Blondel, 2000), or may become flightless (Roff, 1994).

The concomitance of a set of phenotypic alterations, often similar in unrelated groups, is also a common theme in domestication, already noted by Darwin (1868). In mammals, this linked set of alterations has been called the 'domestication syndrome' (Wilkins et al., 2014), and includes increased tameness, shortening of the rostrum, reduced brain size relative to body size (Kruska, 2005), floppiness of the ears, curliness of the tail and depigmented skin and fur (Herre \& Röhrs, 1990). Breeding experiments on silver foxes, Vulpes vulpes (Linnaeus, 1758) since 1959 (Belyaev, 1969) showed that selection for tameability resulted not only in the desired increased tameness, but also in aberrant pigmentation, floppy ears, rolled and shortened tails, shorter limbs, shortened, flattened and widened rostra, smaller brains, earlier onset of sexual maturity and the ability to perceive human gestures, indicating that these phenotypic features are coupled (Trut, 1999; Trut, Plysnina \& Oskina, 2004; Trut, Oskina \& Kharlamova, 2009; Hare et al., 2005). 
Similar experiments on brown rats, Rattus norvegicus (Berkenhout, 1769), initiated by Belyaev as well also yielded tame and aggressive strains, where, as in the foxes, tame rats have shorter, flatter and wider muzzles (Singh et al., 2017) and a higher frequency of white spots than the aggressive rats (Albert et al., 2009).

This morphological covariation of phenotypic features in domestic animals is generally explained as due to particular changes of the neural crest cell migration (Crockford, 2002; Montague et al., 2014; Wilkins, Wrangham \& Fitch, 2014; Sánchez-Villagra, Geiger \& Schneider, 2016). The selection for tameability results in developmental deficits in the neural crest cells (multipotent stem cells that arise from the dorsal part of the neural tube in vertebrate embryos), which cause most of the characteristics of the 'domestication syndrome' (Wilkins, Wrangham \& Fitch, 2014). The variation in pigmentation in domesticates is then likely a pleiotropic effect of alleles influencing traits that are related to tameability.

In this respect it is interesting to note the similarity regarding 'naiveté' between the 'island syndrome' and the 'domestication syndrome'. Native island species are often ecologically naive relative to native mainland species. Ecological naiveté is defined as "the tendency for long-term inhabitants of low diversity and disharmonic (unbalanced) islands to lose their capacities for detecting, avoiding or otherwise coping with competitors, predators and parasites from the mainland or otherwise more-balanced and species-rich assemblages - i.e., species at least initially absent from these islands" (cited from Lomolino, 2016:8). An often-cited example is the Falkland wolf (Dusicyon australis), initially even considered a feral domestic dog, because of its remarkable tameness and, among others, white on its tail tip, muzzle and lower limbs (CluttonBrock, 1977), but this was dismissed on the basis of divergence time between this species and its ancestor (Slater et al., 2009; Austin et al., 2013). Darwin (1839) was struck by so much naivety, and foresaw this species' fast extinction, analogous to that of the dodo; indeed, the last individual was killed less than 50 years later.

Irrespective of the genetic and developmental background of the 'domestication syndrome', it has been noted that changes in pigmentation are one of the first traits to appear during the domestication of brown rats selected for tameness (Trut, 1999, Trut, Oskina \& Kharlamova, 2009). Pigmentation changes in the form of increased occurrence of white patches of fur were also observed in a free-living population of wild house mice, Mus musculus domesticus Schwarz \& Schwarz, 1943, that were experimentally kept at an uninhabited barn, fed ad libitum and regularly handled in the course of 14 years (Geiger, Sánchez-Villagra \& Lindholm, 2018). The repeated and frequent exposure to humans in combination with abundant food and absence of predators resulted in an indirect selection for tameness (Geiger, Sánchez-Villagra \& Lindholm, 2018), with as it seems similar covariation of features of the 'domestication syndrome', in this case white fur patches and shorter snouts. Depigmentation might thus be a useful indicator for the detection of the early stages of evolutionary changes in murids which are typical for the 'domestication syndrome'. The 'domestication syndrome' might have a partial developmental similarity with the 'island syndrome' as far as increased naiveté (loss of anti-predator strategies) 
113 is concerned. If that is the case, one would expect increased depigmentation (especially white 114 patches and brown regions) in natural insular populations on islands with the highest levels of 115 insularity (low biodiversity, small size, high isolation). The opposite, increased pigmentation or 116 melanism, is linked to insularity only in lizards, but the higher prevalence of melanistic colour 117 morphs in more densely settled urban contexts in squirrels (Garroway et al., 2018) and ship rats 118 (Ondrias, 1966), as well as in the latter species on the Galápagos Islands (Patton, Yang, Myers, 119 1975) and Hawaii (Tomich, 1968), suggests that both decreased and increased pigmentation may 120 be expected in insular and/or commensal settings. Here, I examine this hypothesis on wild

121

122

123

124

125

126

127

128

129

130

131

132

133

134

135

136

137

138

139

140

141

142

143

144

145

146

147

148

149

150 populations of the Polynesian rat, Rattus exulans (Peale, 1848) from the islands of the Pacific and insular Southeast Asia.

The Polynesian rat has vastly extended its geographic range through human-mediated transport (Fig. 1) starting c. 4000 years ago (Roberts, 1991) and has been established in mainland Southeast Asia, the Greater and Lesser Sunda islands, the Moluccas, the Philippines, New Guinea, New Zealand and practically all inhabited Pacific islands for at least six centuries (Corbet \& Hill 1992; Musser \& Carleton 2005); additionally, it has been reported from Taiwan and Miyakojima of the southern Ryukyu Islands (arrival likely less than a century ago; Motokawa et al. 2001) and Adele Island, northern Australia (arrival c. 130 years ago; Boyle et al. 2004). On the islands outside its native range, it lives as a human commensal in houses, granaries, gardens, cultivated lands, plantations, anthropogenic scrubland, secondary forest and slightly altered primary forests near habitats maintained by humans (Musser, 1977; Corbet \& Hill, 1992), where it is regularly exposed to humans. In this respect it is relevant to note that a number of historical accounts describe this rat as not shy towards humans (e.g. Von Kotzebue, 1821 for the Marshall Islands) and easy to catch (Peale, 1848 for the Society Islands).

Evolutionary divergence is expected to be greatest in the following populations: those on islands with reduced competitor and predator stress through relaxed selection (Whittaker \& FernandezPalacios, 2007; Lomolino, Riddle \& Whittaker, 2017), those on small islands (Lomolino et al., 2012; van der Geer, 2018) and those with greater residence times (Lomolino et al., 2013; van der Geer, Lomolino \& Lyras, 2018). The hypothesis is that these populations of Polynesian rats will show the highest incidence of aberrant coat patterns.

\section{Materials \& Methods}

Dried and prepared skins of the Polynesian (or Pacific) rat, Rattus exulans, were studied at the American Museum of Natural History (New York, US), the Smithsonian Institution (Washington, US) and Te Papa Tongarewa National Museum of New Zealand (Wellington, NZ) (for specimen numbers, see Data S1). Total number of specimens was 3034, of which 370 originated from a total of 7 mainland countries (see Table 1 and Data S1 for details). The islands are classified in five biogeographical regions that differ in biodiversity and average colonisation period by the focal species. Numbers of island specimens are as follows per group: Melanesia ( $n=757$ from 21 islands), Micronesia ( $n=292$ from 29 islands), Polynesia ( $n=424$ from 37 
151 islands), Sunda Shelf Islands ( $\mathrm{n}=478$ from 12 islands) and Wallacea ( $\mathrm{n}=722$ from 18 islands).

152 Palawan and its satellites are considered here as part of the Sunda Shelf, following Cranbrook 153 (2000), who maintains a connection with Borneo during the Last Glacial Maximum (see,

154 however, Voris (2000) who dismisses any connection with Borneo during the Late Pleistocene, 155 based on sea-level reconstructions). The remainder of the Philippines are oceanic in origin, 156 except for Mindoro, which originated as a portion of the Asian continental shelf, and have never 157 been connected to a mainland (van der Geer et al., 2010). They are here considered together with 158 Wallacea on grounds of its similar isolation from the Asian and Australian continental shelves. 159 Bali was connected to Java during the Late Pleistocene (Voris, 2000), and is thus classified with

160 161

162 the Sunda Shelf Islands. Offshore islands are considered together with the respective main island.

The biogeographical regions differ in the composition of their faunas (see Data S2 for number of ecologically relevant native competitors and predators, based on fauna lists provided by van der Geer, Lomolino \& Lyras, 2017, 2018). For example, while Sunda Shelf islands (both Greater and Lesser Sunda Islands) and parts of Melanesia have native competitors and predators, Wallacea has only native competitors, whereas Polynesia and Micronesia have no competitors or predators at all. Introduced potentially relevant predators consists of feral cats in this case. Their impact on population dynamics of introduced rats is, however, negligible (Parsons et al., 2018) and their presence is not taken into account here. Time in isolation is taken from Kirch, 1984; Roberts, 1991; Matisoo-Smith et al., 1999; Cranbrook, 2000; Anderson \& White, 2001; Anderson \& Sinoto, 2002; Anderson, 2005, 2008; Green, Jones \& Sheppard, 2008; Summerhayes et al., 2010; Hanebuth et al., 2011; Wilmshurst et al., 2011; Burley, Weisler \& Zhao, 2012; Denham, Ramsey \& Specht, 2012; Carson et al., 2013; Clark et al., 2016; McCoy et al., 2016; West et al., 2017 (details per island provided in Data S2; see also Fig. 1) and binned in classes of 1,000 years each, except for the highest class (class 5), which represents time in isolation exceeding 5,000 years without upper limit. Surface area was $\log _{10}$ transformed before statistical analyses.

Aberrant coat colour and patterns are those that differ substantially (evaluated by me and, where needed, checked by the photographer and curatorial staff) from those seen in the rest of the population from the same island or country, thus taking natural variation within populations into account. Both upper- and undersides are taken into account. Slightly darker or lighter coat colours are considered normal, taking seasonal variations into account. Dorsal pelage in $R$. exulans varies per region between grey-brown to reddish-brown; ventral pelage is dark grey or pale buffy with pale grey or white tips (Tate, 1935; Atkinson \& Moller, 1990). White-bellied individuals, lacking grey bases to the white belly hair, are typical for and restricted to Flores (Lesser Sunda Islands; Indonesia) (Schwarz \& Schwarz, 1967) and Adele Island (Australia) (Tate, 1951); the mtDNA haplotype (Rx083) is the same in the Flores sample from Liang Bua cave and Adele Island, while different elsewhere (Hingston, 2015), supporting a recent introduction by Indonesian fishermen. 
189 I here take the mainland populations as reference, and not those from the Lesser Sunda Islands.

190

191

192

193

194

195

196

197

198

199

200

201

202

203

204

205

206

207

208

209

210

211

212

213

214

215

216

217

218

219

220

221

222

223

224

225

226

227
Flores was indicated as the place of origin of the exulans group (Schwarz, 1960), instead of mainland Southeast Asia (Tate, 1935), based on the presence here of white-bellied forms. Schwarz and Schwarz (1967) considered these the "wild form" and the ancestor of all commensal types. They interpreted the loss of a white belly as an adaptation to the darker indoor environment. Genomics confirmed this hypothesis was (Thomson et al., 2014), Note, however, that Musser (1981) did not find significant morphological differences between $R$. exulans from Flores and the rest of the Lesser Sunda Islands; in addition, no fossil or subfossil $R$. exulans have yet been reported from Flores, despite the rich murid fossil record with stratigraphic contexts. Although the exact place of origin has important implications for tracing human migrations through insular Southeast Asia, it has much less relevance to the distribution of coat polymorphisms.

Aberrant coat patterns are here defined in terms of leucism and melanism. Leucistic mammals lack pigment to a varying degree, ranging from a few white spots to (nearly) all white or yellowish. In contrast to albinistic mammals, that congenitally lack pigment altogether, eyesight is not usually impaired and the nose, eyes and feet are coloured as typical for the species. Melanistic mammals in contrast show an increased expression of black or brown pigment (melanine). Mixed white and brown / black animals are generally known as piebald.

Potentially, three types of sampling biases could have influenced the results presented here. Particular collectors may have either preferred or discarded specimens with an aberrant or otherwise remarkable coat pattern. Particular curators may have discarded particular aberrant specimens during curatorial activities. Finally, sample sizes are not equal for all regions: the samples from Wallacea and Melanesia are twice the size of those from the other three island regions as well as the mainland, potentially increasing the chance of finding abnormalities in the first two regions. I here assume the collector's and curatorial bias to be similar across the regions. Furthermore, the specimens are derived from only three major collections, limiting the curatorial bias to differences among these collections. Overlap in geographical provenance between the collections further reduces this bias.

The variables (number of competitors and predators, island area, time in isolation and cases of aberrant coat patterns) were not normally distributed (after testing using the Shapiro-Wilk test; Shapiro \& Wilk, 1965; Table S1)), therefore Chi-square tests were used to test whether the aberrant coat patterns were evenly distributed over the archipelagoes and the time bins, and whether there was a relation with the number of native predators and competitors. The groupings were based on biogeographical provinces (Mainland, Melanesia, Micronesia, Polynesia, Sunda Shelf Islands, Wallacea), as this corresponds best to biodiversity and residence time (see above), absence / presence of aberrant coat patterns and residence time (binned in steps of 1,000 years each, see above). The number of native predators was binned as zero, 1, 2 or more predators; the number of native competitors was binned as zero, 1-5, 6-30 or more competitors (see Data S2 for the islands; mainlands fall in the latter bins). Regarding island area ( $\log _{10}$ transformed), a 
228

229

230

231

232

233

234

235

236

237

238

239

240

241

242

243

244

245

246

247

248

249

250

251

252

253

254

255

256

257

258

259

260

261

262

263

264

265

non-parametric Kruskal-Wallis one-way analysis of variance test (by lack of normality) was used to determine if there was a correlation between coat colour polymorphism (Siegel, 1956), with the number of aberrant coat patterns as grouping variable (three samples: 0,1 or 2 aberrant coats) and island area, and similarly, to test for a correlation between island area and number of competitors. Statistical analyses were performed using Past 3.16 (Hammer, Harper \& Ryan, 2001). Significance level alpha $=0.05$.

\section{Results}

Out of 3034 skins of $R$. exulans, 15 skins showed aberrant coat colour and/or pattern, evenly distributed over the sexes (Tables 2 and 3) and over the geographic distribution (Fig. 2); for summary statistics, see Table S1. The single aberrant coat pattern from the mainland (Vietnam) is an albino (Fig. 3A, B). Albinos are, however, characterised by a congenital failure to produce melanin in otherwise normal melanocytes. In this way, potential changes in the coat colour pattern are not expressed and can thus not be traced. Albinos can further be recognised by their red eyes and pink noses and ears, as a result of this total lack of pigmentation. This specimen is omitted from the analyses. Note that albino specimens are reported in less than $2 \%$ of rodent species (Romero et al., 2018), and that the specimen shown here (USNM 357550) is, by my knowledge, the first reported case in $R$. exulans.

The aberrant coat colour patterns from the islands by contrast either show signs of increased pigmentation (melanism) or reduced pigmentation (leucism). The depigmentation can be complete (Fig. 3C, D; Fig. S1A), partial (piebald; Fig. 4) or restricted to a single spot (Fig. 5, Fig. S1B) or a few strands of hair (Fig. 2I). The piebald specimen (Hawaii) has normal, wildtype colouration on the head, shoulders and a wide mid-dorsal stripe or band extending to the base of the tail, as typical for the "hooded" phenotype of laboratory rats ( $R$. norvegicus); different from the hooded rats is the patchy brown pigmentation on the white parts. Based on the typical light buff colour (pale yellow) of the albino R. exulans (Fig. 3A-B) as a result of total lack of melanin in the melanocytes, I here interpret the evenly buff coloured specimens as different phases of leucism with differential expression of melanin, where a total lack corresponds to the colour of the albino (but with different congenital background) (Fig. 3C-D; Fig. S2A). The latter specimens are not albinos because they have black eyes, coloured ears and toe pads, and presumably black eyes (eyes were removed, but aberrant features are typically noted down, which was not the case here). The melanistic specimens are either evenly darker coloured, including (Fig. 6A-B) or excluding the underside (Fig. 6C-D; Fig. S2B-C), or bear irregular patches of increased pigmentation, either on both upper- and underside (Fig. 6E-F) or only at the underside (Fig. 6G-H).

The difference in distribution of aberrant coat colour patterns over the six biogeographical regions is not significant $\left(\mathrm{Chi}^{2}, \mathrm{p}=0.08\right.$, all patterns; $\mathrm{p}=0.06$, melanism and leucism considered separately; Table S2), nor is the distribution different between the mainland and all islands considered together $\left(\mathrm{Chi}^{2}, \mathrm{p}=0.162\right)$. Within Polynesia, coat polymorphisms are restricted to the 
266 Hawaiian archipelago and Line Islands, both at the north-eastern limit of the distribution. The majority of aberrant coat patterns are various phases of leucism.

268

269

270

271

272

273

274

275

276

277

278

279

280

281

282

283

284

285

286

287

288

289

290

291

292

293

294

295

296

297

298

299

300

301

302

303

Time in isolation cannot predict the occurrence of aberrant coat patterns $\left(\mathrm{Chi}^{2}, \mathrm{p}=0.673\right)$, whereas the numbers of native predators and native competitors as well as log transformed island area are significantly correlated to the number of aberrant coat patterns $\left(\mathrm{Chi}^{2}, \mathrm{p}=0.017, \mathrm{Chi}^{2}, \mathrm{p}=\right.$ 0.002 and Kruskal-Wallis, $\mathrm{p}<0.001$, respectively). The latter two variables are, however, positively correlated to the number of aberrant coat patterns. This counterintuitive result is probably driven by the positive correlation between island area and competitors (species-area relationship; Kruskal-Wallis, $\mathrm{p}<0.001$ ), and the correlation coat polymorphism and island area is here considered redundant. Test results are provided in Tables S1 and S2.

\section{Discussion}

Insular populations of Polynesian rats show a higher incidence of individuals with an aberrant coat pattern than those of mainland Polynesian rats, which lacked leucistic and/or melanistic individuals altogether. This higher incidence is, however, not statistically significant, perhaps as a result of the smaller sample size of mainland rats (12\% of the total). The coat polymorphisms found on the islands are not significantly correlated with time in isolation. Indeed, although the Philippines and Sulawesi were among the first islands to be reached by the Lapiti people on their way into the Pacific some 3,500-4,000 years ago (Anderson, 2005), and half the reported cases are from these islands, an equal amount of cases of aberrant coats is from Polynesian islands that were reached only some 925-657 years ago (West et al., 2017). Colour polymorphisms seem not to have been facilitated by the sequential colonisation (the founder effect) either, as seen by the lack of a clear distribution pattern of (nearly) identical aberrant coat patterns (Figs 1,2). However, note that within Polynesia, the aberrant cases are restricted to the most remote part of the north-eastern distribution (Hawaii and Line Islands). A sequence of founding events, such as is the case for the Polynesian dispersal from Near to Remote Oceania is likely to reduce genetic variation (e.g. Clegg et al., 2002). However, this cannot explain the results presented here, as similar polymorphisms would be expected to occur on related islands, which is not the case.

The level of predation and murid competition varies substantially between the regions. Whereas Polynesia and Micronesia both lack ecologically relevant native predators and competitors, Wallacea and the Sunda Shelf islands house a suite of native murids to compete with, as well as native predators in the case of the latter islands. The unexpected positive correlation between coat colour polymorphisms and amount of ecologically relevant competitors might be an artefact instead of representing a causal relationship, because these results are strongly influenced by the islands Luzon and Sulawesi, each with two aberrant specimens as well as an exceptionally high number of native murids. A simple mechanism that could explain the observation that the more competitors, the more aberrant coat patterns are present, is that potential expansion of Polynesian rats into non-commensal niches is hampered by resident murid species. I can here only speculate that this obligatory restriction to the human commensal niche, and the inherent reduced fear for 
304

305

306

307

308

309

310

311

312

313

314

315

316

317

318

319

320

321

322

323

324

325

326

327

328

329

330

331

332

333

334

335

336

337

338

339

340

341

342

humans, caused the higher number of abnormalities on (very) biodiverse islands. For Sulawesi and Luzon, there are indeed indications that this might be valid: its occurrence on Sulawesi was recorded mostly in and around villages, and only sparsely in secondary forest (Musser, 1977) and on Luzon it is considered always associated with human habitation, except when there are few native murids (Heaney et al., 2010). Similar scenarios have been suggested for introduced house mice, which are usually outcompeted by other rodent species in non-anthropogenic habitats (e.g. Berry, Cuthbert \& Peters, 1982).

Depigmentation in the form of white patches on the trunk as presented by Polynesian rats from Java, Hawaii, Kauai, Luzon and Sulawesi has been observed in practically all domestic animal species (mouse, rat, guinea pig, rabbit, dog, cat, fox, mink, ferret, pig, reindeer, sheep, goat, cattle, horse, camel, alpaca and guanaco; Darwin, 1868; Belyaev \& Trut, 1989; Gariépy, Bauer \& Cairns, 2001; Trut, Oskina \& Kharlamova, 2009). In the brown rat, R. norvegicus, typically, the irregular white patches occur in particular sites: just below the throat and above the eyes, the paws and the tip of the tail. This is, however, not what we observe in the Polynesian rats, where the patches are predominantly located in the shoulder region and on the back of the thorax. Only the piebald specimen from Hawaii has an irregular placement of white patches all over its body and skull with the exception of the midsagittal region over its entire length, approaching observed colour patterns in domestic brown rats. White patches in rats are generally considered as evolved along the commensal pathway of domestication (Sánchez-Villagra, Geiger \& Schneider, 2016), and the Polynesian rat seems to follow this pattern, being a human commensal species in its introduced range, except for islands abandoned by the Polynesians centuries ago (e.g. the Mystery Islands). This pathway is characterized by unintentional selection for tameness (Zeder, 2012a, b; Larson \& Fuller, 2014). In the case of island evolution, this tameness may also be a case of ecological naivité driven by the decreased number of predators and competitors relative to the mainland (e.g., the number of native mammalian predators feeding on rats of Vietnam is 24; data from IUCN, 2019). Indeed, a significant correlation was found between native predators and incidence of aberrant coat patterns. This is best illustrated by the presence of the most extreme aberrant coat pattern (the piebald specimen) on an island (Hawaii) without any native mammals, except for bats.

In general, evolutionary changes of island mammals in their new environment may have been adaptive as well as non-adaptive (e.g. Whittaker \& Fernandez-Palacios, 2007). In that light, a possible scenario for the higher occurrence of melanistic coats on Pohnpei, Kure Atoll and Kauai (Hawaii) could be that darker coat patterns have an adaptive advantage in avoiding birds of prey because such a colour spectrum corresponds to the background colour of their habitats: dark basaltic rocks covered in rain forests. However, the lack of increased melanism on other basaltic islands fails to confirm such a pattern. The lack of a clear pattern and the overall low percentage of melanism seems unable to support a functional explanation. In addition, although piebald coat patterns have the potential to be adaptive in rainforest environments (Hawaii), the high incidence 
343

344

345

346

347

348

349

350

351

352

353

354

355

356

357

358

359

360

361

362

363

364

365

366

367

368

369

370

371

372

373

374

375

376

377

378

379

380

381

of piebald patterns in domestic animals rather favours an explanation towards a higher degree of tameness under low predatory pressure.

The observed colour polymorphisms here are limited to variations in the expression of redyellow and/or black-brown (distribution, expression, intensity). These two colour ranges in vertebrates are mainly controlled by two genes, being the melanocortin-1 receptor gene $(M c 1 r)$ and its antagonist, the Agouti signalling protein gene (Asip) (Hubbard et al., 2010). These genes work together in controlling the pigment expression of eumelanin (black-brown) and pheomelanin (red-yellow) in melanocytes. Melanistic furs in natural populations are most commonly associated with mutations in Mclr (e.g. Mundy et al., 2004), In mice, Agouti further regulates the differences between dorsal and ventral pigmentation and may be responsible for the switching off of pigment production altogether (Vrieling et al., 1994). Dark buff or rufous undersides (contrary to the usually white ventral pelage) were observed in the most remote population of the large Japanese field mouse, Apodemus speciosus (Temminck, 1844), on the Izu Islands (Tomozawa et al., 2014), explained as the result of loss of genetic variation and changes in the frequency of an allele for a mutation in Asip. Laboratory mice with such mutations showed enhanced pigmentation (yellow pheomelanin) of the ventral pelage (Vrieling et al., 1994), similar to the pattern (dark buff with blackish tail) observed in the large Japanese field mouse on Miyake island (Tomozawa et al., 2014). Such a mechanism may explain the Polynesian rat specimen with irregular dark buff patches especially at its underside. White spotting in rats and mice, including hooding, is caused by mutations in one or more of the genes that regulate neural crest-derived melanoblast development (e.g. Kit, Pax3, Mitf and Sox 10), leading to reduction and/or loss of mature melanocytes (Baxter et al., 2004; Kuramoto et al., 2012). White spots can be associated with disorders in other neural crest derived tissues or elsewhere due to pleiotropic effects, including microphthalmia, deafness, spina bifida and sterility (Baxter et al., 2004), most of which would be fatal or at least severely impact fitness in any wild living rat population. The pale-yellow coat pattern in the Polynesian rat might be explained by the diluting effects of the gene(s) that control the intensity of pigment, in combination with alleles coding for brown instead of black. In mice, this combination is the result of homozygosity for the recessive allele in both genes (Griffiths et al., 2000). In parallel, the ash grey dorsal fur of the Kiritimati specimen might be due to reduced pigment production in combinations with a black colour. In short, a number, or perhaps all, of the aberrant coats in Polynesian rats might be explained simply by loss of genetic variation, due to drift and founder effects.

Whereas phases of leucism, including piebald, can all be ascribed to homozygosity for recessive alleles in one or more genes (see above), this is not always the case for melanism. In laboratory mice, for example, mutations in alleles of Mclr leads to dominant melanism, whereas mutations in alleles of Agouti usually cause recessive melanism. The latter was found in four geographically widely separated North American deer mouse populations, which suggests that melanism-inducing mutations in Agouti might be more common than generally thought (Kingsley et al., 2009). The low incidence (three specimens) of generalised melanism in 
382

383

384

385

386

387

388

389

390

391

392

393

394

395

396

397

398

399

400

401

402

403

404

405

406

407

408

409

410

411

412

413

414

415

416

\section{7}

418

419

Polynesian rats indicates such a recessive autosomal inheritance of melanism. The occurrence of two of these, plus the single piebald specimen, in the same archipelago might further indicate a general loss of heterozygosity in this remote destination.

In contrast, the absence of coat colour polymorphisms on Borneo and Sumatra may indicate a regular gene flow from the adjacent mainland populations in Southeast Asia. A similar lack of aberrant coat patterns in central east Polynesia (e.g. Society and Cook Islands, Samoa) might be explained by the existence of a broad interaction sphere or a large "homeland region", central to a number of smaller interaction spheres, as indicated by evidence from mtDNA phylogenies (Matisoo-Smith et al., 1998), with the concurrent regular gene flow. By contrast, the Polynesian rats of Hawaii have close affinities with those of the Marquesas and the Society Islands, but whether gene flow continued after the initial introduction(s) remains unclear (Matisoo-Smith et al., 1998). The occurrence of a piebald specimen favours the hypothesis of a high degree of isolation. The limitation of rats with white patches on their dorsal pelage to Luzon, Sulawesi and Java might confirm the existence of a regional interaction sphere including the Philippines, Borneo and Sulawesi, unrelated to that of Oceania, as inferred from the restriction of mtDNA haplogroup I to the Philippines, Borneo and Sulawesi (Matisoo-Smith \& Robins, 2004; a cautionary note: Java was not sampled in the latter study). Cytochrome B haplotype distributions also confirm a connection between the Philippines (Negros), Borneo and Sulawesi, all sharing H1, which occurs nowhere else (Thomson et al., 2014). Saipan (Mariana Islands) has the basic Pacific haplotype (H8), which gives no further clue on phylogeny; the other islands of my dataset were not sampled.

\section{Conclusions}

Results revealed that populations of the Polynesian rat introduced onto Southeast Asian and Pacific islands show a trend towards a higher incidence of coat polymorphisms, such as white patches, piebald coats, leucism and melanism as compared to mainland populations from their native range, although not statistically significant. No correlation could be found between this incidence and time in isolation on the focal island. A negative correlation was found between the number of native predators and the incidence of aberrant coat patterns. The higher incidence of abnormal coat patterns on islands with a high level of native murid biodiversity is here tentatively explained as linked to a more exclusively human commensal life. The white patches, including piebald patterns, observed in Polynesian rats, are here explained as a pleiotropic effect of unintentional selection for tameness (commensal pathway of domestication), possibly accelerated by insularity (limited gene flow, lack of predators), whereas melanistic coat patterns are more likely the effect of isolation on gene frequencies and distribution (founding events) and thus not necessarily linked to increased tameness.

\section{Acknowledgements}

I thank Darrin Lunde (United States National Museum of Natural History), Neil Duncan, Ross MacPhee, Marisa Surovy, Eleanor Hoeger, Brian O’Toole (American Museum of Natural 
420

421

422

423

424

425

426

427

428

429

430

431

432

433

434

435

436

437

438

439

440

441

442

443

444

445

446

447

448

449

450

451

452

453

454

455

456

457

458

History) and Colin Miskelly (Te Papa Tongarewa National Museum of New Zealand) for permission to access the collections under their care and their technical assistance. I thank Stergio Intzes for his assistance with the statistical analyses, George Lyras for making the figures and Tamatea McGlinn for proofreading the text. A special thanks goes to Bartholomeus van der Geer for much-appreciated technical support, making the photographs and discussing the initial idea. The reviewers are thanked for their thorough and critical reviews, which helped greatly to improve the manuscript.

\section{References}

Adler GH, Levins R. 1994. The island syndrome in rodent populations. Quarterly Review of Biology 69:473-490.

Albert FW, Carlborg Ö, Plyusnina I, Besnier F, Hedwig D, Lautenschläger S, Lorenz D, McIntosh J, Neumann C, Richter H, Zeising C, Kozhemyakina R, Shchepina O, Kratsch J, Trut L, Teupser D, Thiery J, Schöneberg T, Andersson L, Pääbo S. 2009. Genetic architecture of tameness in a rat model of animal domestication. Genetics 182:541-554. DOI 10.1534/genetics.109.102186

Anderson A. 2005. Crossing the Luzon Strait: archaeological chronology in the Batanes Islands, Philippines and the regional sequence of Neolithic dispersal. Journal of Austronesian Studies 1:25-44.

Anderson A. 2008. Traditionalism, interaction, and long-distance seafaring in Polynesia. Journal of Island and Coastal Archaeology 3:240-250. DOI 10.1080/15564890802340000

Anderson A., Sinoto Y. 2002. New radiocarbon dates of colonization sites in East Polynesia. Asian Perspectives 41:242-257.

Anderson A., White P. 2001. Prehistoric settlement on Norfolk Island and its Oceanic context. Records of the Australian Museum, Supplement 27:135-141.

Atkinson IAE, Moller H. 1990. Kiore. In The handbook of New Zealand mammals (ed., C King), pp. 175-192. Auckland, New Zealand: Oxford University Press.

Austin JJ, Soubrier J, Prevosti FJ, Prates L, Trejo V, Mena F, Cooper A. 2013. The origins of the enigmatic Falkland Islands wolf. Nature Communications 4:1552. DOI $10.1038 /$ ncomms 2570

Baxter LL, Hou L, Loftus SK, Pawan WJ. 2004. Spotlight on spotted mice: a review of white spotting mouse mutants and associated human pigmentation disorders. Pigment Cell Research 17:215-224. DOI 10.1111/j.1600-0749.2004.00147.x

Belyaev DK. 1969. Domestication of animals. Science Journal (UK) 5:47-52.

Belyaev DK, Trut LN. 1989. The convergent nature of incipient forms and the concept of destabilizing selection. In Vavilov's Heritage in Modern Biology (eds YA Ovchinnikov, IA Rapoport), pp. 155-169. Moscow, Russia: Nauka.

Berkenhout J. 1769. Outlines of the Natural History of Great Britain and Ireland. London, UK: P. Elmsly. 
459

460

461

462

463

464

465

466

467

468

469

470

471

472

473

474

475

476

477

478

479

480

481

482

483

484

485

486

487

488

489

490

491

492

493

494

495

496

497

Berry RJ, Cuthbert A, Peters J. 1982. Colonization by house mice: an experiment. Journal of Zoology 198:329-336.

Blondel J. 2000. Evolution and ecology of birds on islands: trends and prospects. Vie et Milieu 50:205-220.

Boekschoten GJ, Sondaar PY. 1972. On the fossil mammalia of Cyprus. Proceedings of the Koninklijke Nederlandse Akademie van Wetenschappen (Series B) 75:306-338.

Bover P. 2004. Noves aportacions al coneixement del gènere Myotragus Bate, 1909 (Artiodactyla, Caprinae) de les illes Balears. Unpublished PhD thesis. Palma de Mallorca: Universitat de les Illes Balears.

Boyle A, Swann G, Willing T, Gale T, Collins L. 2004. Adele Island Bird Survey Report. Unpublished report. Kensington, Australia: Government of Western Australia, Department of Biodiversity, Conservation and Attractions.

Burley DV, Weisler M, Zhao XJ. 2012. High precision U/Th dating of first polynesian settlement. PLoSONE 7 (11):e48769. DOI 10.1371/journal.pone.0048769

Carson MT, Hung H-C, Summerhayes G, Bellwood P. 2013. The pottery trail from Southeast Asia to Remote Oceania. Journal of Island and Coastal Archaeology 8:17-36. DOI 10.1080/15564894.2012.726941

Clark JT, Quintus S, Weisler M, St Pierre E, Nothdurft L, Feng Y. 2016. Refining the chronology for West Polynesian colonization: new data from the Samoan archipelago. Journal of Archaeological Science Reports 6:266-274. DOI 10.1016/j.jasrep.2016.02.011

Clegg SM, Degnan SM, Kikkawa J, Moritz C, Estoup A, Owens IPF. 2002. Genetic consequences of sequential events by an island-colonizing bird. Proceedings of the National Academy of Sciences of the United States of America 99:8127-8132. DOI 10.1073/pnas.102583399.

Clutton-Brock J. 1977. Man-made dogs. Science 197:1340-1342. DOI 10.1126/science.197.4311.1340

Cody ML. 1971. Ecological aspects of reproduction. Avian Biology 1:461-512.

Cooper Jr WE, Pérez-Mellado V. 2012. Historical influence of predation pressure on escape by Podarcis lizards in the Balearic Islands. Biological Journal of the Linnean Society 107:254-268. DOI 10.1111/j.1095-8312.2012.01933.x

Corbet GB, Hill JE. 1992. The Mammals of the Indomalayan Region: A Systematic Review. Oxford, UK: Oxford University Press.

Cranbrook Earl of. 2000. Northern Borneo environments of the past 40,000 years: archaeozoological evidence. The Sarawak Museum Journal 55:61-109.

Crockford SJ. 2002. Animal domestication and heterochronic speciation. In Human evolution through developmental change (eds N Minugh-Purvis, KJ McNamara), pp. 122-153. Baltimore, MD: Johns Hopkins University Press.

Darwin C. 1839. Voyages of the Adventure and Beagle, Volume III, Journal and remarks. 18321836. London UK: Henry Colburn 
498

499

500

501

502

503

504

505

506

507

508

509

510

511

512

513

514

515

516

517

518

519

520

521

522

523

524

525

526

527

528

529

530

531

532

533

534

535

536

Darwin C. 1868. The variation of animals and plants under domestication. London, UK: John Murray.

de Vos J, van der Geer AAE. 2002. Major patterns and processes in biodiversity: taxonomic diversity on islands explained in terms of sympatric speciation. In World islands in prehistory, international insular investigations, $V$ Deia International Conference of Prehistory (eds WH Waldren, JA Ensenyat), pp. 395-405. Bar International Series 1095. Oxford, UK: Archaeopress.

Denham T, Ramsey CB, Specht J. 2012. Dating the appearance of Lapita pottery in the Bismarck Archipelago and its dispersal to Remote Oceania. Archaeology in Oceania 47:39-46. DOI 10.1002/j.1834-4453.2012.tb00113.x

Desachaux C. 1961. Moulages endocraniennes de bovidés fossiles. Annales de Paléontologie 47:51-73.

Falk D, Hildebolt C, Smith K, Morwood MJ, Sutikna T, Brown P, Jatmiko, Wayhu Saptomo E, Brunsden B, Prior F. 2005. The brain of LB1, Homo floresiensis. Science 308:242-245. DOI 10.1126/science.1109727

Foster JB. 1964. The evolution of mammals on islands. Nature 202:234-235. DOI $10.1038 / 202234 \mathrm{a} 0$

Gariépy J-L, Bauer DJ, Cairns RB. 2001. Selective breeding for differential aggression in mice provides evidence for heterochrony in social behaviours. Animal Behavior 61:933947. DOI 10.1006/anbe.2000.1700

Garroway CJ, Fletcher QE, Balzer E, Ferry C, Kinnunen R, Schmidt C, Solmundson K, Manitoba U, Winnipeg U. 2018. Eastern grey squirrel colour morphs and urban adaptation. Annual Meeting of the Society for Integrative and Comparative Biology, January 3-7, 2018, San Francisco, CA. Meeting Abstracts:133.

Geiger M, Sánchez-Villagra MR, Lindholm AK. 2018. A longitudinal study of phenotypic changes in early domestication of house mice. Royal Society Open Science 5:172099. DOI 10.1098/rsos.172099

Green RC, Jones M, Sheppard P. 2008. The reconstructed environment and absolute dating of SE-SZ-8 Lapita site on Nendö, Santa Cruz, Solomon Islands. Archaeology in Oceania 43:49-61. DOI 10.1002/j.1834-4453.2008.tb00030.x

Griffiths AJF, Miller JH, Suzuki DT, Lewontin RC, Gelbart W. 2000. Introduction to genetic analysis, $7^{\text {th }}$ ed., 960 pp. New York, USA: W.H. Freeman.

Hammer Ø, Harper DAT, Ryan PD. 2001. PAST: Paleontological Statistics software package for education and data analysis. Palaeontologia Electronica 4:9. http://palaeoelectronica.org/2001_1/past/issue1_01.htm

Hanebuth TJJ, Voris HK, Yokoyama Y, Saito Y, Okuno JI. 2011. Formation and fate of sedimentary depocenters on Southeast Asia's Sunda Shelf over the past sea-level cycle and biogeographic implications. Earth-Science Reviews 104:92-110. DOI 10.1016/j.earscirev.2010.09.006 
537

538

539

540

541

542

543

544

545

546

547

548

549

550

551

552

553

554

555

556

557

558

559

560

561

562

563

564

565

566

567

568

569

570

571

572

573

574

575

Hare B, Plyusnina I, Ignacio N, Schepina O, Stepika A, Wrangham R, Trut L. 2005. Social cognitive evolution in captive foxes is a correlated by-product of experimental domestication. Current Biology 15:226-230. DOI 10.1016/j.cub.2005.01.040

Heaney LR, Dolar ML, Balete DS, Esselstyn JA, Rickart EA, Sedlock JL. 2010. Synopsis of Philippine mammals. Available at: www.fieldmuseum.org/philippine_mammals (accessed 24 December 2018).

Herre W, Röhrs M. 1990. Haustiere-zoologisch gesehen, i-xiii, pp. 1-412. Stuttgart, Germany: Gustav Fischer Verlag.

Hingston M. 2015. Phylogeography of the commensal Rattus exulans with implications for its use as bioproxy for human migrations. PhD Auckland University, New Zealand.

Huang WS. 2007. Ecology and reproductive patterns of the agamid lizard Japalura swinhonis on an East Asian island, with comments on the small clutch sizes of island lizards. Zoological Science 24:181-188. DOI 10.2108/zsj.24.181

Hubbard JK, Uy JAC, Hauber ME, Hoekstra HE, Safran RJ. 2010. Vertebrate pigmentation: from underlying genes to adaptive function. Trends in Genetics 26:231239. DOI 10.1016/j.tig.2010.02.002

IUCN. 2019. The IUCN Red List of Threatened Species. Version 2018-2. http://www.iucnredlist.org. Accessed Jan 01, 2019.

Kaifu Y, Baba H, Sutikna T, Morwood MJ, Kubo D, Saptomo EW, Jatmiko, Awe RD, Djubiantono T. 2011. Craniofacial morphology of Homo floresiensis: description, taxonomic affinities, and evolutionary implication. Journal of Human Evolution 61:644682. DOI 10.1016/j.hevol.2011.08.008

Kingsley EP, Manceau M, Wiley CD, Hoekstra HE. 2009. Melanism in Peromyscus is caused by independent mutations in Agouti. PLoS ONE 4(7):e6435. DOI 10.1371/journal.pone.0006435

Kirch PV. 1984. The Evolution of Polynesian Chiefdoms. Cambridge, UK: Cambridge University Press.

Kruska DC. 2005. On the evolutionary significance of encephalization in some eutherian mammals: effects of adaptive radiation, domestication, and feralization. Brain Behaviour and Evolution 65:73-108. DOI 10.1159/000082979

Kuramoto T, Nakanishi S, Ochiai M, Nakagama H, Voigt B, Serikawa T. 2012. Origins of albino and hooded rats: implications from molecular genetic analysis across modern laboratory rat strains. PLOS ONE 7(8):e43059. DOI 10.1371/journal.pone.0043059

Larson G, Fuller D. 2014. The evolution of animal domestication. Annual Review of Ecology, Evolution, and Systematics 45:115-136. DOI 10.1146/annurev-ecolsys-110512-135813

Laurie EMO, Hill JE, 1954. List of Land Mammals of New Guinea, Celebes and Adjacent Islands, 1758-1952. London, UK: British Museum of Natural History.

Leinders JJM. 1984. Hoplitomerycidae fam. nov. (Ruminantia, Mammalia) from Neogene fissure fillings in Gargano (Italy). Scripta Geologica 70:1-51. 
576

577

578

579

580

581

582

583

584

585

586

587

588

589

590

591

592

593

594

595

596

597

598

599

600

601

602

603

604

605

606

607

608

609

610

611

612

613

614

615

Leinders JJM, Sondaar PY. 1974. On functional fusions in footbones of ungulates. Zeitschrift für Säugetierkunde 39:109-115.

Linnaeus C. 1758. Systema naturce per regna tria naturce, secundum classes, ordines, genera, species, cum characteribus, differentiis, synonymis, locis. Holmia (Stockholm), Sweden: Laurentius Salvius.

Lomolino MV. 1985. Body size of mammals on islands: the island rule re-examined. The American Naturalist 125:310-316. DOI 10.1086/284343

Lomolino MV. 2005. Body size evolution in insular vertebrates: generality of the island rule. Journal of Biogeography 32:1683-1699. DOI 10.1111/j.1365-2699.2005.01314x

Lomolino MV. 2016. The unifying, fundamental principles of biogeography: Understanding Island Life. Frontiers of Biogeography 8:e29920. DOI 10.21425/F5FBG29920

Lomolino MV, Riddle BR, Whittaker RJ. 2017. Biogeography. Biological diversity across space and time (5th ed.). Sunderland, MA: Sinauer Associates Inc.

Lomolino MV, Sax DF, Palombo MR, van der Geer AA. 2012. Of mice and mammoths: evaluations of causal explanations for body size evolution in insular mammals. Journal of Biogeography 39:842-854. DOI 10.1111/j.1365-2699.2011.02656.x

Lomolino MV, van der Geer AAE, Lyras GA, Palombo MR, Sax D, Rozzi R. 2013. Of mice and mammoths: generality and antiquity of the island rule. Journal of Biogeography 40:1427-1439. DOI 10.1111/jbi.12096

Lyras GA, van der Geer AAE, Dermitzakis MD, de Vos J. 2006. Cynotherium sardous, an insular canid (Mammalia: Carnivora) from the Pleistocene of Sardinia (Italy), and its origin. Journal of Vertebrate Paleontology 26:735-745. DOI 10.1671/02724634(2006)26[735:CSAICM]2.0.CO;2

Matisoo-Smith E, Robins JH. 2004. Origins and dispersals of Pacific peoples: evidence from mtDNA phylogenies of the Pacific rat. Proceedings of the National Academy of Sciences of the USA 101:9167-9172. DOI 10.1073/pnas.0403120101.

Matisoo-Smith E, Roberts RM, Irwin GJ, Allen JS, Penny D, Lambert DM. 1998. Patterns of prehistoric human mobility in Polynesia indicated by mtDNA from the Pacific rat. Proceedings of the National Academy of Sciences of the USA 95:15145-15150.

McCoy MD, Alerson HA, Hemi R, Cheng H, Lawrence Edwards R. 2016. Earliest direct evidence of monument building at the archaeological site of Nan Madol (Pohnpei, Micronesia) identified using ${ }^{230} \mathrm{Th} / \mathrm{U}$ coral dating and geochemical sourcing of megalithic architectural stone. Quaternary Research 86:295-303. DOI 10.1016/j.ygres.2016.08.002

Meijaard E. 2003. Mammals of south-east Asian islands and their Late Pleistocene environments. Journal of Biogeography 30:1245-1257. DOI 10.1046/j.13652699.2003.00890.x

Montague MJ, Li G, Gandolfi B, Khan R, Aken BL, Searle SMJ, Minx P, Hillier LW, Koboldt DC, Davis BW, Driscoll CA, Barr CS, Blackistone K, Quilez J, LorenteGaldos B, Marques-Bonet T, Alkan C, Thomas GWC, Hah MW, Mentti-Raymond M, O'Brien SJ, Wilson RK, Lyons LA, Murphy WJ, Warren WC. 2014. 
616

617

618

619

620

621

622

623

624

625

626

627

628

629

630

631

632

633

634

635

636

637

638

639

640

641

642

643

644

645

646

647

648

649

650

651

652

653

654

655

Comparative analysis of the domestic cat genome reveals genetic signatures underlying feline biology and domestication. Proceedings of the National Academy of Sciences of the USA 111:17230-17235. DOI 10.1073/pnas.1410083111

Motokawa M, Lu K-H, Harada M, Lin L-K. 2001. New records of the Polynesian rat Rattus exulans (Mammalia: Rodentia) from Taiwan and the Ryukyus. Zoological Studies 40: 299-304.

Moyá-Solá S. 1979. Morfología functional del tarso en el género Myotragus Bate, 1909 (Artiodactyla, Rupicaprini). Acta Geologica Hispanica 3:87-91.

Mundy NI, Badcock NS, Hart T, Scribner K, Janssen K, Nadeau NJ. 2004. Conserved genetic basis of a quantitative plumage trait involved in mate choice. Science 303:1870 1873. DOI 10.1126/science.1093834

Musser GG. 1977. Epimys benguetensis, a composite, and one zoogeographic view of rat and mouse faunas in the Philippines and Celebes. American Museum Novitates 2624:1-15.

Musser GG. 1981. The giant rat of Flores and its relatives east of Borneo and Bali. Bulletin of the American Museum of Natural History 169:67-176.

Musser GG, Carleton MD. 2005. Superfamily Muroidea. In Mammal Species of the World: A Geographic and Taxonomic Reference (eds DE Wilson, DA Reeder), pp. 894-1531. Baltimore, MD: The John Hopkins University Press.

Omland KE. 1997. Examining two standard assumptions of ancestral reconstructions: repeated loss of dichromatism in dabbling ducks (Anatini). Evolution 51:1636-1646. DOI 10.1111/j.1558-5646.1997.tb01486.x

Ondrias JC. 1966. The taxonomy and geographical distribution of the rodents of Greece. Saugetierkundliche Mitteilungen 14:1-134.

Pafilis P, Meiri S, Foufopoulos J, Valakos E. 2009. Intraspecific competition and high food availability are associated with insular gigantism in a lizard. Die Naturwissenschaften 96:1107-1113. DOI 10.1007/s00114-009-0564-3

Parsons MH, Banks PB, Deutsch MA, Munshi-South J. 2018. Temporal and space-use changes by rats in response to predation by feral cats in an urban ecosystem. Frontiers of Ecology and Evolution 6: 146. DOI 10.3389/fevo.2018.00146

Patton JL, Yang SY, Myers P. 1975. Genetic and morphological divergence among introduced rat populations (Rattus rattus) of the Galapagos archipelago, Ecuador. Systematic Zoology 24:296-310.

Peale TR. 1848. Mammalia and ornithology. United States exploring expeditions during the years 1838, 1839, 1840, 1841, 1842 under the command of Charles Wilkes. National Reports of the U.S. Exploration Survey 8:17-338.

Quintana J, Köhler M, Moyà-Solà S. 2011. Nuralagus rex, gen. et sp. nov., an endemic insular giant rabbit from the Neogene of Minorca (Balearic Islands, Spain). Journal of Vertebrate Paleontology 31:231-240. DOI 10.1080/02724634.2011.550367

Raia P, Barbera C, Conte M. 2003. The fast life of a dwarfed giant. Evolutionary Ecology 17:293-312. DOI 10.1023/A:1025577414005

Peer] reviewing PDF | (2018:11:32784:2:0:NEW 29 Mar 2019) 
656 Roberts M. 1991. Origin, dispersal routes, and geographic distribution of Rattus exulans, with

657

658

659

660

661

662

663

664

665

666

667

668

669

670

671

672

673

674

675

676

677

678

679

680

681

682

683

684

685

686

687

688

689

690

691

692

693

694

special reference to New Zealand. Pacific Science 45:123-130.

Roff DA. 1994. The evolution of flightlessness: is history important? Evolutionary Ecology 8:639-657. DOI 10.1007/BF01237847

Romero V, Racines-Márquez CE, Brito J. 2018. A short review and worldwide list of wild albino rodents with the first report of albinism in Coendou rufescens (Rodentia: Erethizontidae). Mammalia 82:509-515. DOI 10.1515/mammalia-2017-0111.

Runemark A, Hansson B, Pafilis P, Valakos ED, Svensson EI. 2010. Island biology and morphological divergence of the Skyros wall lizard Podarcis gaigeae: a combined role for local selection and genetic drift on color morph frequency divergence? BMC Evolutionary Biology 10:269. DOI 10.1186/1471-2148-10-269.

Sánchez-Villagra MR, Geiger M, Schneider RA. 2016. The taming of the neural crest: a developmental perspective on the origins of morphological covariation in domesticated mammals. Royal Society Open Science 3:160107. DOI 10.1098/rsos.160107

Schwarz E. 1960. Classification, origin and distribution of commensal rats. Bulletin of the World Health Organization 23:411-416.

Schwarz E, Schwarz HK. 1943. The wild and commensal stocks of the house mouse, Mus musculus Linnaeus. Journal of Mammalogy 24:59-72. DOI 10.2307/1374781.

Schwarz E, Schwarz HK. 1967. A monograph of the Rattus rattus group. Annals Escuela Nacional Ciencias Biologicas 14:79-178.

Siegel S. 1956. Nonparametric statistics for the behavioral sciences. New York, US: McGrawHill.

Shapiro SS, Wilk MB. 1965. An analysis of variance test for normality (complete samples). Biometrika 52:591-611.

Singh N, Albert FW, Plyusnina I, Trut L, Pääbo S, Harvati K. 2017. Facial shape differences between rats selected for tame and aggressive behaviors. PLOS ONE 12(4):e0175043. DOI 10.1371/journal.pone.0175043

Slater GJ, Thalmann O, Leonard JA, Schweizer RM, Koepfli K-P, Pollinger JP, Rawlence NJ, Austin JJ, Cooper A, Wayne RK. 2009. Evolutionary history of the Falklands wolf. Current Biology 19:R937-R938.

Sondaar PY. 1977. Insularity and its effect on mammal evolution. In Major patterns in vertebrate evolution (eds MN Hecht, PL Goody, BM Hecht), pp. 671-701. New York, NY: Plenum.

Summerhayes GR, Leavesley M, Fairbairn A, Mandui H, Field J, Ford A, Fullagar R. 2010. Human adaptation and plant use in highland New Guinea 49,000 to 44,000 years ago. Science 330:78-81. DOI 10.1126/science.1193130

Tate GHH. 1935. Rodents of the genera Rattus and Mus from the Pacific Islands, collected by the Whitney South Sea expedition, with a discussion of the origin and races of the Pacific Island rat. Bulletin of The American Museum of Natural History 68:145-178.

Peer) reviewing PDF | (2018:11:32784:2:0:NEW 29 Mar 2019) 
695

696

697

698

699

700

701

702

703

704

705

706

707

708

709

710

711

712

713

714

715

716

717

718

719

720

721

722

723

724

725

726

727

728

729

730

731

732

733

734

Tate GHH. 1951. Rodents of Australia and New Guinea. Results of Archbold expedition 65. Bulletin of the American Museum of Natural History 97:183-430.

Temminck CJ. 1844. Aperçu general et spécifique sur les Mammifères qui habitant le Japon et les iles qui en dependent. In Fauna Japonica (eds PF von Siebold, CJ Temminck, H Schlegel), pp. 1-59. Lugduni Batavorum (Leiden), Netherlands: Apud Auctorem.

Thomson V, Aplin KP, Cooper A, Hisheh S, Suzuki H, Maryanto I, Yap G, Donnellan SC. 2014. Molecular genetic evidence for the place of origin of the Pacific rat, Rattus exulans. PLoS ONE 9(3):e91356. DOI 10.1371/journal.pone.0091356

Tomich PQ 1968. Coat color in wild populations of the roof rat in Hawaii. Journal of Mammalogy 49:74-82.

Tomozawa M, Nunome M, Suzuki H, Ono H. 2014. Effect of founding events on coat colour polymorphism of Apodemus speciosus (Rodentia: Muridae) on the Izu Islands. Biological Journal of the Linnean Society 113:522-535. DOI 10.1111/bij.12348

Trut LN. 1999. Early canid domestication: the farm-fox experiment. American Scientist 161:160-169. DOI 10.1511/1999.2.160

Trut LN, Oskina I, Kharlamova A. 2009. Animal evolution during domestication: the domesticated fox as a model. Bioessays 31:349-360. DOI 10.1002/bies.200800070

Trut LN, Plyusnina IZ, Oskina IN. 2004. An experiment on fox domestication and debatable issues of evolution of the dog. Russian Journal of Genetics 40:644-655. DOI 10.1023/B:RUGE.0000033312.92773.c1

van den Bergh GD. 1999. The late Neogene elephantoidbearing faunas of Indonesia and their palaeozoogeographic implications. Scripta Geologica 117:1-419.

van den Bergh GD, Rokus Awe Due, Morwood MJ, Sutikna T, Jatmiko, Wahyu Saptomo E. 2008. The youngest Stegodon remains in southeast Asia from the Late Pleistocene archaeological site Liang Bua, Flores, Indonesia. Quaternary International 181:16-48. DOI 10.1016/j.quatint.2007.02.001

van der Geer AAE. 2005. Island ruminants and the evolution of parallel functional structures. In Les ongules holarctiques du Pliocene et du Pleistocene. Actes Colloque international Avignon, 19-22 septembre (ed. E Crégut), pp. 231-240. Quaternair Hors-série 2. Paris, France: Maison de la géologie.

van der Geer AAE. 2014. Parallel patterns and trends in functional structures in extinct island mammals. Integrative Zoology 9:167-182. DOI 10.1111/1749-4877.12066.

van der Geer AAE, Lomolino M, Lyras GA. 2017. Islands before man: the species-area relationship during the late Pleistocene. Journal of Biogeography 44: 995-1006. DOI $10.1111 / j b i .12857$

van der Geer AAE, Lomolino M, Lyras GA. 2018. On being the right size - do aliens follow the rules. Journal of Biogeography 45:515-529. DOI 10.1111/jbi.13159

van der Geer AAE, de Vos J, Lyras G, Dermitzakis M. 2006. New data on the Pleistocene Cretan deer Candiacervus sp. II (Mammalia, Cervinae). Courier Forschungsinstitut Senckenberg 256:131-137. 
735

736

737

738

739

740

741

742

743

744

745

746

747

748

749

750

751

752

753

754

755

756

757

758

759

760

761

762

763

764

765

766

767

768

769

770

771

772

773

van der Geer AAE, de Vos J, Dermitzakis M, Lyras G. 2010. Evolution of island mammals: adaptation and extinction of placental mammals on islands. Oxford, UK: WileyBlackwell.

van der Geer AAE, Lyras GA, Mitteroecker P, MacPhee RDE. 2018. From Jumbo to Dumbo: cranial shape changes in elephants and hippos during phyletic dwarfing. Evolutionary Biology 45:303-317. DOI 10.1007/s11692-018-9451-1

van der Made J. 1999. Biogeography and stratigraphy of the Mio-Pleistocene mammals of Sardinia and the description of some fossils. Deinsea 7:337-360.

Van Valen L. 1973. A new evolutionary law. Evolutionary Theory 1:1-33.

Vervust B, Grab I, van Damme R. 2007. Differences in morphology, performance and behaviour between recently diverged populations of Podarcis sicula mirror differences in predation pressure. Oakes 116:1343-1352. DOI 10.1111/j.0030-1299.2007.15989.x

Von Kotzebue O. 1821. Entdeckungsreise in die Südsee und nach der Beringstrasse zu Erforschung einer nordöstlichen Durchfahrt. Unternommen in den Jahren 1815, 1816, 1817 und 1818. Weimar, Germany: Hoffmann.

Voris HK. 2000. Maps of the Pleistocene sea levels in Southeast Asia: shorelines, river systems and time durations. Journal of Biogeography 27:1153-1167. DOI 10.1046/j.13652699.2000.00489.x

Vrieling H, Duhl DM, Millar SE, Miller KA, Barsh GS. 1994. Differences in dorsal and ventral pigmentation result from regional expression of the mouse agouti gene. Proceedings of the National Academy of Sciences of the United States of America 91: 5667-5671.

Wallace AR. 1880. Island life, or the phenomena and causes of insular faunas and floras. London, UK: MacMillan.

West K, Collins C, Kardailsky O, Kahn J, Hunt TL, Burley DV, Matisoo-Smith E. 2017. The Pacific rat race to Easter Island: tracking the prehistoric dispersal of Rattus exulans using ancient mitochondrial genomes. Frontiers in Ecology and Evolution 5:52. DOI 10.3389/fevo.2017.00052

Weston EM, Lister AM. 2009. Insular dwarfism in hippos and a model for brain size reduction in Homo floresiensis. Nature 459:85-88. DOI 10.1038/nature07922

Whittaker RJ, Fernandez-Palacios JM. 2007. Island biogeography. Ecology, evolution, and conservation, 2nd edn. Oxford, UK: Oxford University Press.

Wilkins AS, Wrangham RW, Fitch WT. 2014. The 'domestication syndrome' in mammals: a unified explanation based on neural crest cell behavior and genetics. Genetics 197:795808. DOI 10.1534/genetics.114.165423

Wilmshurst JM, Hunt TL, Lipo CP, Anderson AJ. 2011. High-precision radiocarbon dating shows recent and rapid initial human colonization of East Polynesia. Proceedings of the National Academy of Sciences of the United States of America 108:1815-1820. DOI 10.1073/pnas.1015876108 
774 Wilson DE, Reeder DAM. 2005. Mammal Species of the World. A Taxonomic and Geographic

775

776

777

778

779

780

781
Reference ( $3^{\text {rd }}$ ed). Baltimore, MD: Johns Hopkins University Press.

Zeder MA. 2012 (a). Pathways to animal domestication. In Biodiversity in agriculture: domestication, evolution, and sustainability (eds P Geptset al.), pp. 227-259. New York, NY: Cambridge University Press.

Zeder MA. 2012 (b). The domestication of animals. Journal of Anthropological Research 68:161-190. DOI 10.3998/jar.0521004.0068.201 


\section{Figure 1}

Schematic map showing simplified routes of human-aided dispersal of Polynesian rats, Rattus exulans

Populations on the Sunda Shelf Islands were isolated since the Last Glacial Maximum when sea level rises disconnected these areas from each other and the mainland. Populations in the Philippines and Wallacea were introduced about 4000-3500 BP. Subsequently, more remote areas were reached starting about 3400-3200 BP (Micronesia, Melanesia). The remotest areas of Polynesia (New Zealand, Hawaii and Easter Island), finally, were settled about 820-720 years ago (Roberts, 1991; Matisoo-Smith et al., 1999; Summerhayes et al., 2010; Wilmshurst et al., 2011; West et al., 2017). Orange: native and introduced range. White: areas without Polynesian rats. Image credit: George Lyras. Map credit:https://d-maps.com/carte.php?num_car=3258\&lang=en.

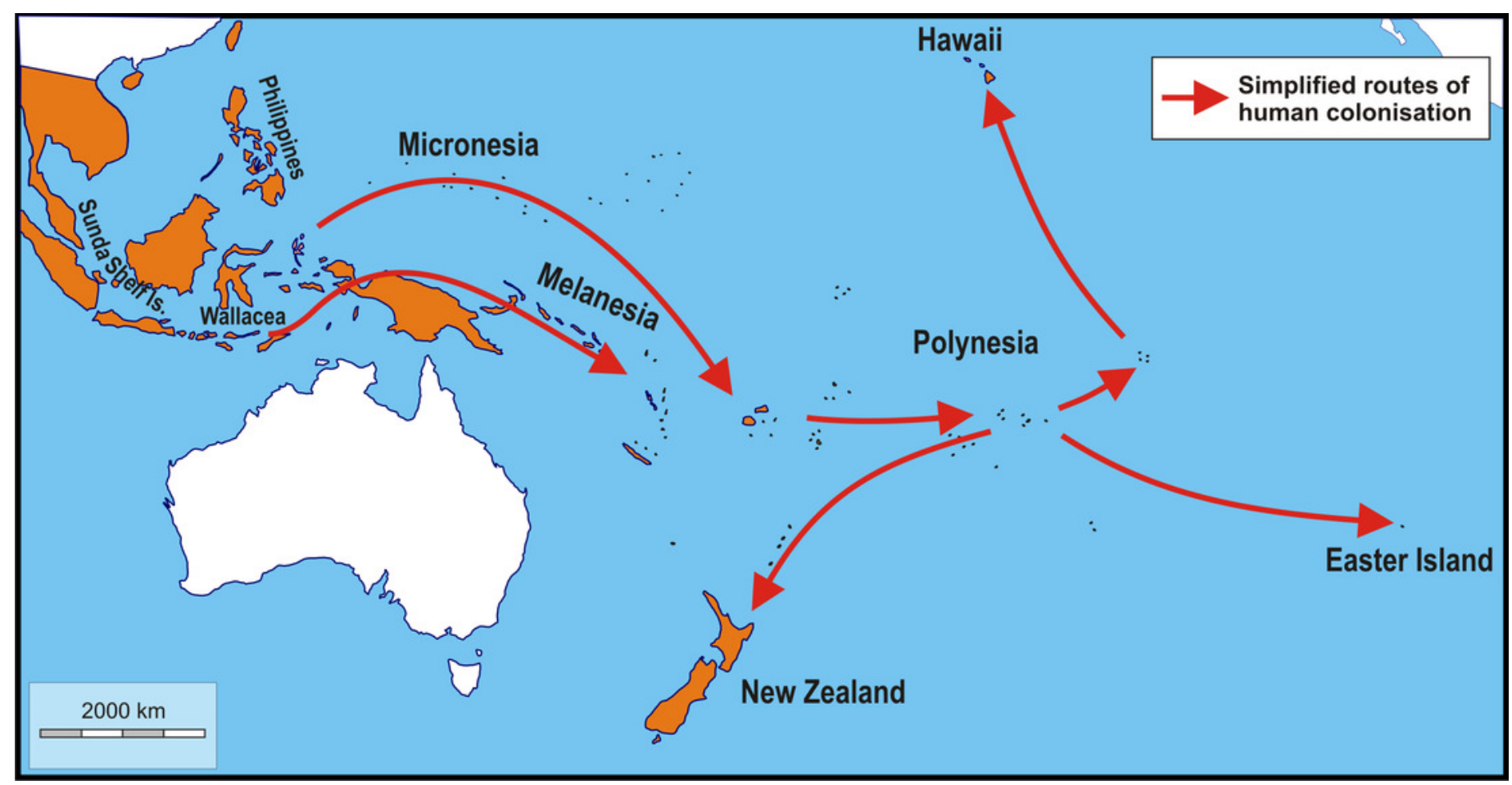




\section{Figure 2}

Schematic map showing the distribution of aberrant coat patterns in Polynesian rats.

The distribution of coat polymorphisms is random over the introduced range. No aberrant coat patterns were found in populations from the native range (mainland Southeast Asia), except for an albino specimen from Vietnam (not indicated here; see Fig. 3). The circles show details of ventral (A) and dorsal skins (B); all skins are shown in full in Figs 3-6 and Figs S1-2. (A) Malenge, Togian Islands, Sulawesi. (B) Sulawesi, Indonesia. (C) Java, Indonesia. (D) Batam, Riau Islands, Sumatra. (E) Mindoro, Philippines. (F) Luzon, Philippines. (G) Pohnpei, Caroline Islands. (H) Kure atoll, Hawaii. (I) Kauai, Hawaii. (J) Hawaii, Hawaii. (K) Kiritimati. For specimen details, see Table 2. Image credit: George Lyras. 


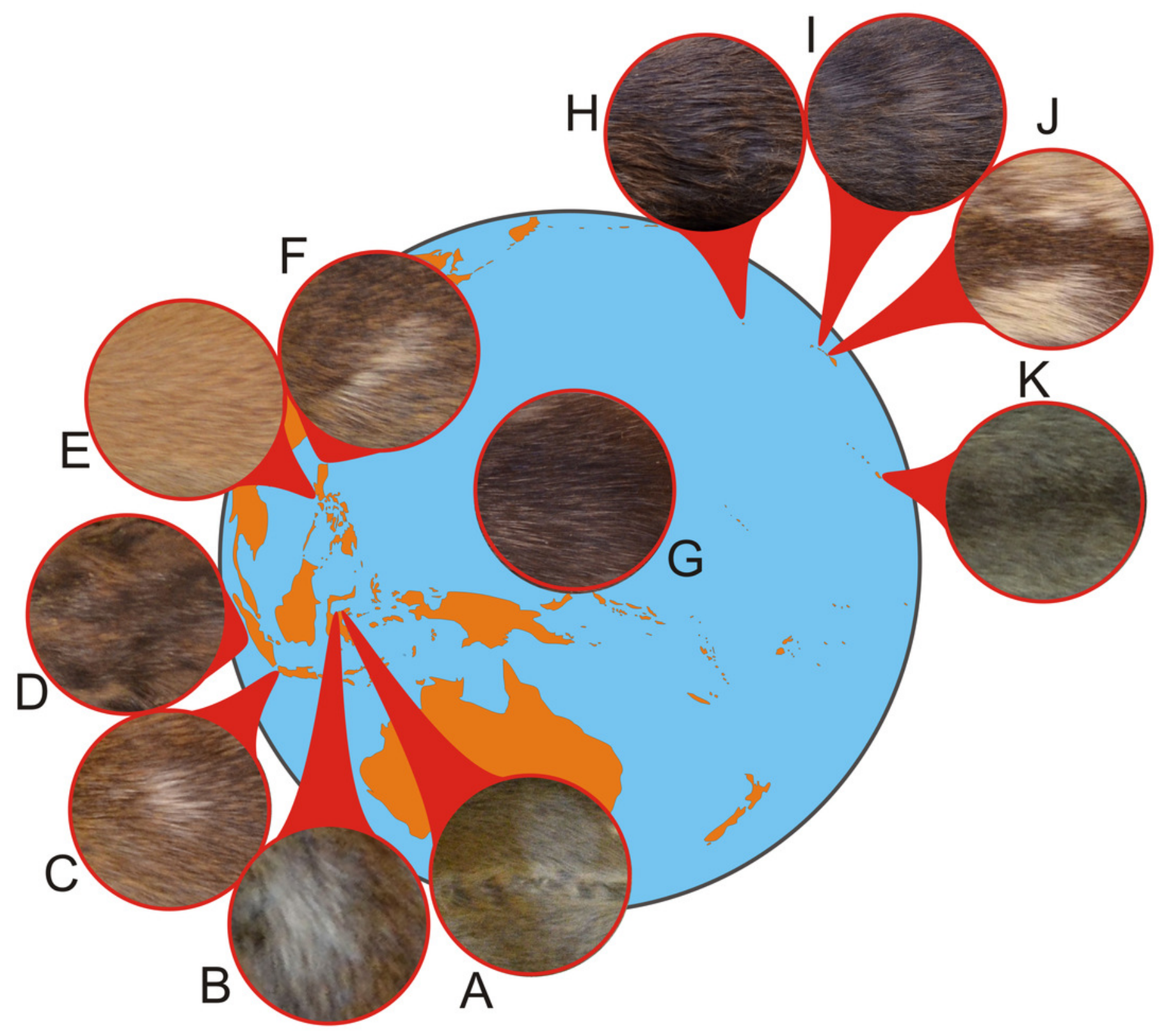




\section{Figure 3}

Albino (A, B) and complete leucistic (C, D) coat patterns in the Polynesian rat.

(A) Albino specimen from Vietnam (USNM 357550, male), dorsal view. (B) Same specimen, ventral view. (C) Light buff coloured (complete leucism) specimen from Mindoro, Philippines (USNM 278589, male), ventral view. Note that Rattus vigoratus as written on the label is a junior synonym for Rattus exulans (Polynesian rat), following Wilson \& Reeder (2005). (D) Same specimen, dorsal view. Photo credits: Bartholomeus van der Geer. 

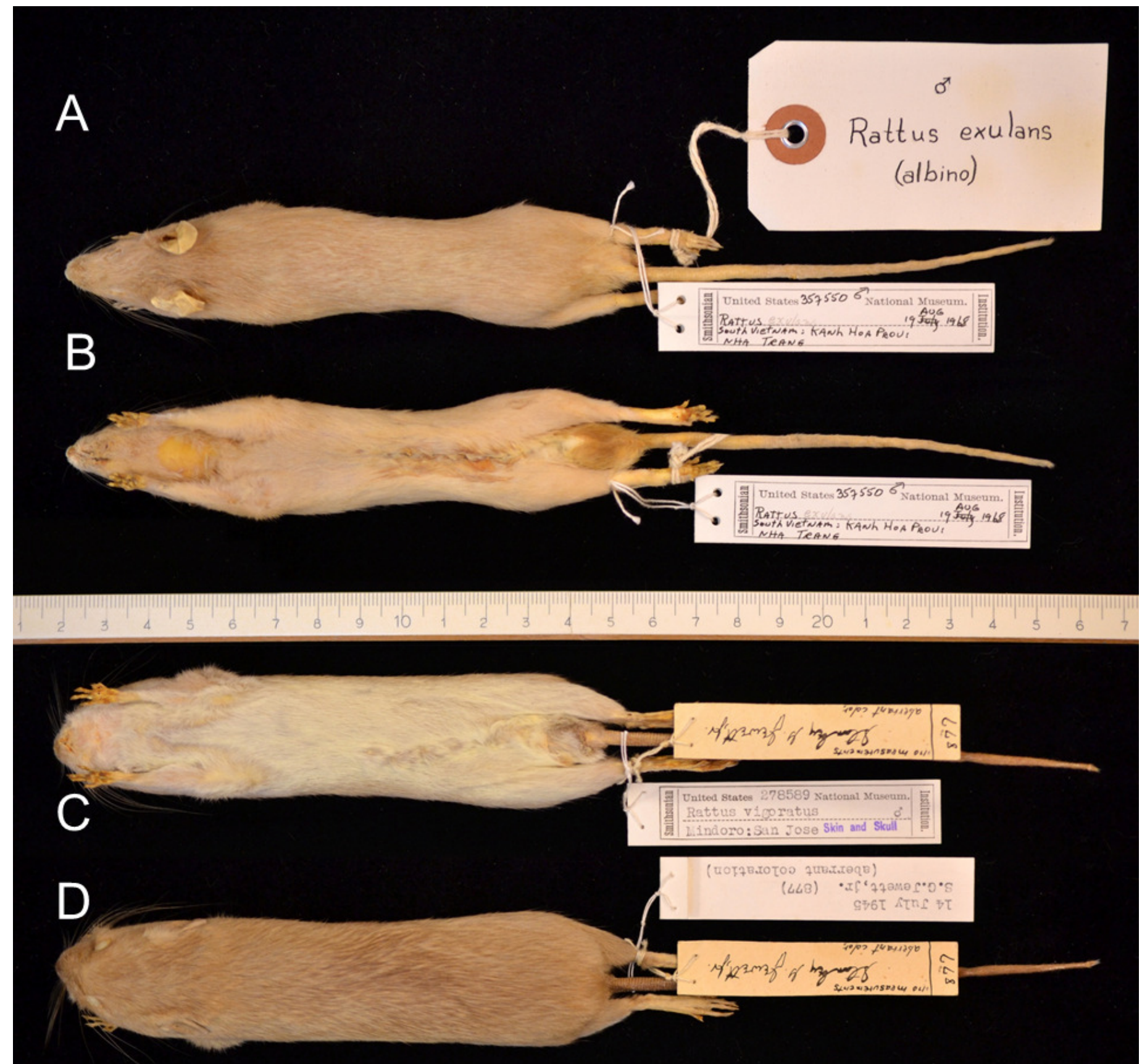


\section{Figure 4}

Piebald coat pattern in an insular Polynesian rat.

The piebald pattern (a mixture of brown and white) is present on the ventral, lateral and dorsal sides in this specimen from Hawaii (USNM 324887, female). Photo credits:

Bartholomeus van der Geer.
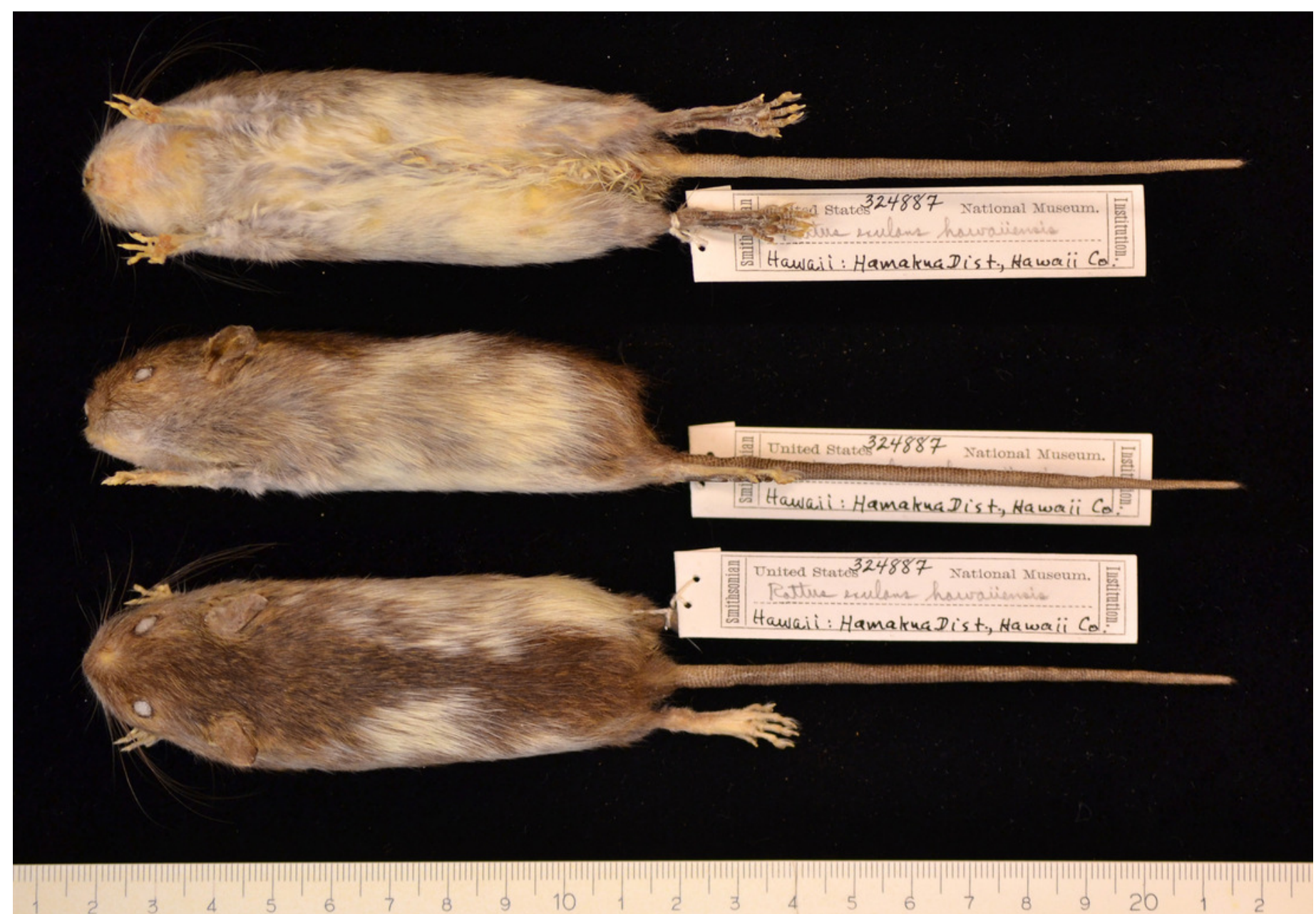


\section{Figure 5}

Insular Polynesian rats showing white patches at the shoulder region.

(A) Specimen from Luzon, Philippines (USNM 145823, male). Note that Epimys querceti as written on this label and the next is a junior synonym for Rattus exulans (Polynesian rat), following Wilson \& Reeder (2005). (B) Specimen from the same locality (USNM 145827, female). (C) Specimen from Java, Indonesia (USNM 138794, male). Photo credits: Bartholomeus van der Geer. 

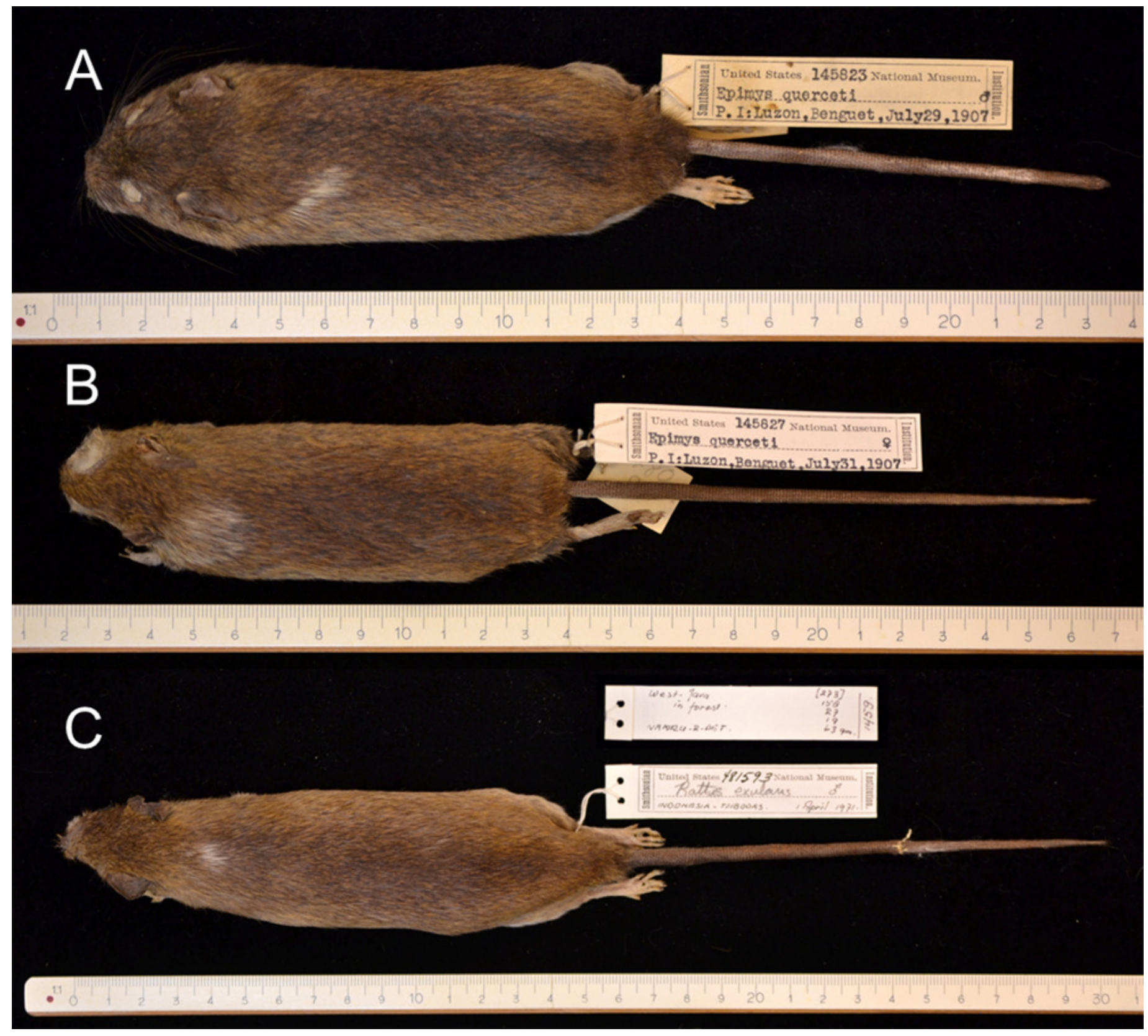


\section{Figure 6}

Insular Polynesian rats with different expressions of melanism (increased pigmentation).

(A) Normal-coloured specimen from Ponape, Caroline Islands (USNM 301998; female), ventral side. (B) Melanistic coloured specimen from the same population (USNM 301999, female), captured at the same day, ventral side. (C) Same specimen as (A), dorsal view. (D) Same specimen as (B), dorsal view. (E) Irregular black patches in a specimen from Batam Island, Sumatra (USNM 143251, female), ventral view. (F) Same specimen, dorsal view. Patches are present on both upper- and underside. Note that Epimys concolor as written on the label is a junior synonym for Rattus exulans (Polynesian rat), following Wilson \& Reeder (2005). (G) Irregular dark buff patches in a specimen from Malenge, Togian Islands, Sulawesi (USNM 153296, male), ventral side. (H) Normal-coloured specimen (USNM 153295, female) from the same locality. Photo credits: Bartholomeus van der Geer. 

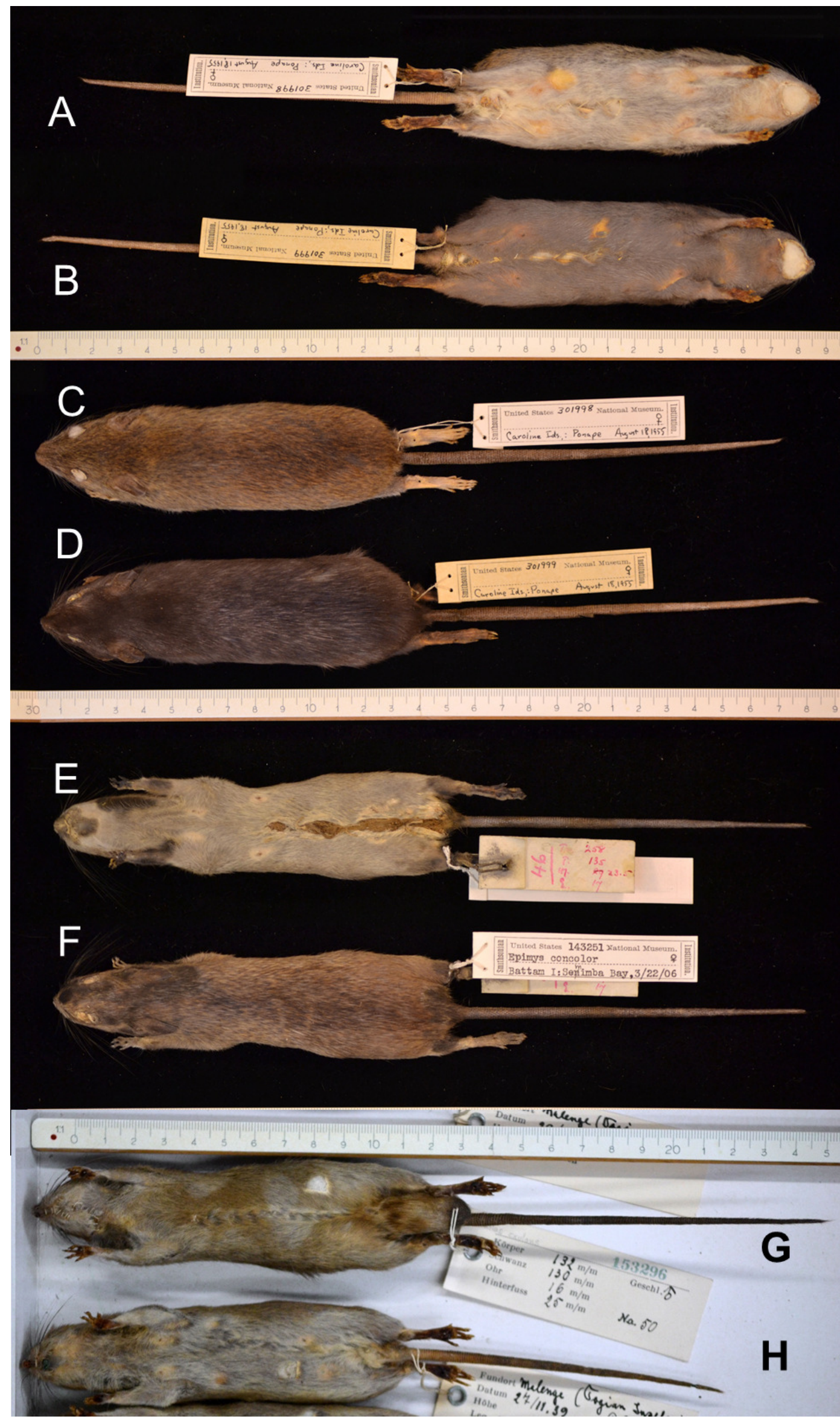

Peer) reviewing PDF | (2018:11:32784:2:0:NEW 29 Mar 2019) 


\section{Table $\mathbf{1}$ (on next page)}

List of mainland countries and islands with number of Polynesian rats sampled in this study. 
Region

Mainland

Melanesia

Micronesia

Polynesia

\section{Country or Island}

Bangladesh
Burma
Laos
Malaysia
Myanmar
Thailand
Vietnam

Bougainville

Efaté

Emirau

Espiritu Santo

Fergusson

Fiji (island N/A)

Goodenough

Grande Terre

Guadalcanal

Kiriwinia Island

Misima Island

New Britain

New Guinea

New Ireland

Normanby Island

Nusi Island

Ontong Java

Rossel Island

Ugi

Vanatinai

Woodlark Island

And atoll

Arno atoll

Babelthuap Island

Bikar atoll

Bikini Atoll

Carlos Island

Caroline Islands (island N/A)

David Island

Dick Island

Enewetok Atoll

Guam

Guguan Island

Kalap Island

Kapingamarangi Atoll

Kayangel Atoll

Koror Island

Kosrae

Kwajalein Atoll

Majuro Atoll

Moen Island

Peleliu Island

Pohnpei

Ponam

Rongelap Atoll

Saipan

Taka Atoll

Tinian Island

Ulithi Atoll

Wake Island

Atafu Atoll

Aunu'U Island

Birnie Atoll

Fakaofo Atoll

Hatutaa Island

Hawaii

Hen Island

\begin{tabular}{lllll} 
female & \multicolumn{2}{c}{ Gender } & & \\
male & unknown & subtotal & total \\
2 & 0 & 0 & 2 & \\
3 & 5 & 0 & 8 & \\
3 & 2 & 0 & 5 & \\
6 & 5 & 0 & 11 & \\
19 & 16 & 0 & 35 & \\
83 & 60 & 4 & 147 & \\
84 & 77 & 1 & 162 &
\end{tabular}

38

17

3

2

11

33

17

15

152

11

3 


Kiritimati
Kanton
Kauai
Kure Atoll
Little Barrier
Manra Island
Macauley
Maui
North Island*
Niuafo'Ou Island
Nukunonu Atoll
Oahu
Ofu
Olosega
Onotoa Atoll
Orona Atoll
Pitcairn
Raoul
Raroia Atoll
Repanga
Rose Atoll
Rurima Rocks
South Island
Stewart
Swains Island
Tahiti
Ta'u Island
Tepoto
Vostok Island
Whakaari

Bali

\section{Borneo}

Borneo, Pulo Balik Kukup

Java

Palawan

Palawan, Balabac Island

Culion

Sumatra

Sumatra, Banka Island

Sumatra, Batam Island

Sumatra, Nias Island

Sumatra, Simeulue

Wallacea

Total

Ambon

Basilan Island

Buru

Busuanga Island

Catanduanes

Halmahera

Leyte

Luzon

Malenge Island

Mindanao

Mindoro

Negros

Panay

Peleng Island

Polillo Island

Samar

Sulawesi

Taliabu

$\begin{array}{lll}1 & 1 & 0 \\ 0 & 3 & 0 \\ 0 & 1 & 0 \\ 8 & 9 & 0 \\ 1 & 0 & 0 \\ 10 & 20 & 2 \\ 1 & 0 & 1 \\ 104 & 104 & 10 \\ 11 & 14 & 0 \\ 24 & 15 & 4 \\ 20 & 23 & 2 \\ 11 & 18 & 2 \\ 4 & 1 & 0 \\ 9 & 4 & 0 \\ 0 & 0 & 1 \\ 4 & 5 & 0 \\ 118 & 147 & 0 \\ 9 & 9 & 1\end{array}$




\section{Table 2 (on next page)}

Polynesian rats with an aberrant coat pattern.

Specimens are first ordered according to the biogeographic region and then on specimen number. The number of ecologically relevant native predators and competitors and island area $\left(\mathrm{km}^{2}\right)$ are from van der Geer, Lomolino \& Lyras $(2017,2018)$, except for Batam (Meijaard, 2003) and Malenge (Laurie \& Hill, 1954). Area is rounded to the nearest integer. 


\begin{tabular}{|c|c|c|c|c|c|c|c|c|}
\hline \multirow{2}{*}{$\begin{array}{l}\text { Region } \\
\text { Mainland }\end{array}$} & \multirow{2}{*}{$\begin{array}{l}\text { Country } \\
\text { Vietnam }\end{array}$} & & \multicolumn{4}{|c|}{ Specimen } & \multirow{2}{*}{$\begin{array}{l}\operatorname{sex} \\
\mathrm{m}\end{array}$} & \multirow{2}{*}{$\begin{array}{l}\text { aberrant coat pattern } \\
\text { albino }\end{array}$} \\
\hline & & & USNM & 357550 & & & & \\
\hline Region & Island & Area & & & $\begin{array}{l}\text { Pred } \\
\text { ators }\end{array}$ & $\begin{array}{l}\text { Compet } \\
\text { itors }\end{array}$ & & \\
\hline \multirow[t]{2}{*}{ Micronesia } & Saipan & 123 & USNM & 277708 & 0 & 0 & $f$ & hazelnut colour (dark buff) \\
\hline & Pohnpei & 334 & USNM & 301999 & 0 & 0 & $f$ & melanistic, also underside \\
\hline \multirow[t]{4}{*}{ Polynesia } & Hawaii & 10,435 & USNM & 324887 & 0 & 0 & $f$ & piebald, mixture of white and brown, also at underside \\
\hline & Kure & 1 & USNM & 338630 & 0 & 0 & $f$ & very dark, toward melanistic \\
\hline & Kauai & 1435 & USNM & 570868 & 0 & 0 & $f$ & very dark, toward melanistic; few white hairs \\
\hline & Kiritimati & 321 & USNM & 338688 & 0 & 0 & $\mathrm{~m}$ & ash grey, toward leucism \\
\hline \multirow[t]{2}{*}{$\begin{array}{l}\text { Sunda } \\
\text { Shelf } \\
\text { Islands }\end{array}$} & Batam & 399 & USNM & 143251 & 0 & 0 & $f$ & $\begin{array}{l}\text { blackish patches, mainly on head and shoulder and } \\
\text { median ridge of back; very clear at underside of } \\
\text { mandible, left cheek and right front leg }\end{array}$ \\
\hline & Java & 138,794 & USNM & 481593 & 13 & 7 & $\mathrm{~m}$ & white spot between the shoulders \\
\hline \multirow[t]{6}{*}{ Wallacea } & Malenge & 13 & $\mathrm{AMNH}$ & 153296 & 0 & 1 & $\mathrm{~m}$ & buff coloured, large irregular patches at underside \\
\hline & Sulawesi & 180,681 & AMNH & 153015 & 1 & 36 & $f$ & white patches on both shoulders \\
\hline & Sulawesi & 180,681 & $\mathrm{AMNH}$ & 153037 & 1 & 36 & $f$ & white patch sagitally on back \\
\hline & Luzon & 109,965 & USNM & 145823 & 0 & 40 & $\mathrm{~m}$ & white patch below left shoulder \\
\hline & Luzon & 109,965 & USNM & 145827 & 0 & 40 & $f$ & white patch at left shoulder \\
\hline & Mindoro & 10,572 & USNM & 278589 & 0 & 6 & $\mathrm{~m}$ & $\begin{array}{l}\text { leucism: buff coloured, slightly darker than albino, } \\
\text { underside almost white ("aberrant color" on label) }\end{array}$ \\
\hline
\end{tabular}




\section{Table 3 (on next page)}

Percentage of aberrant coat patterns of Polynesian rats per region.

The time spent is an average value, estimated based on the majority of the relevant islands (see Fig. 1). Abnormalities are the combined cases of melanism and leucism. The albino specimen from the Mainland is here excluded (see Results section) 


$\begin{array}{lllllll}\text { Region } & \begin{array}{l}\text { Time } \\ \text { spent in } \\ \text { situ (ka) }\end{array} & \begin{array}{l}\text { Number of } \\ \text { specimens }\end{array} & \text { Abnormalities } & & \\ \text { Mainland } & 2200 & 370 & \text { total } & \% & \text { female } & \text { male } \\ \text { Melanesia } & 3.4-3.2 & 757 & 0 & 0 & 0 & 0 \\ \text { Micronesia } & 1.75 & 292 & 2 & 0 & 0 & 0 \\ \text { Polynesia } & 0.80 & 424 & 4 & 0.68 & 2 & 0 \\ \text { Sunda Shelf } & 12 & 478 & 2 & 0.42 & 3 & 1 \\ \text { Wallacea } & 4-3.5 & 722 & 6 & 0.83 & 3 & 1 \\ \text { Total } & & \mathbf{3 0 4 3} & \mathbf{1 4} & \mathbf{0 . 4 6} & \mathbf{7} & 3\end{array}$

